\title{
JUAN DE TORQUEMADA, NICHOLAS OF CUSA AND PIUS II ON THE ISLAMIC PROMISE OF PARADISE
}

\author{
Thomas M. Izbicki \\ Rutgers University
}

\begin{abstract}
Western Christianity had a long history of polemics against Islam. That included rejecting Muhammad's idea of paradise as excessively «carnal». In the mid-15th century, three members of the Roman curia took differing approaches to the Otto-mans as Muslims. Pius II tried to persuade the sultan to give up Islam, offering him a «better» paradise. Cardinal Nicholas of Cusa sought evidence of the gospels in the Qur'an, but he rejected the Prophet's «carnal» view of the afterlife. Cardinal Juan de Torquemada, a Dominican, offered a more thorough and negative view of Islam, denouncing carnality but also treating the Qur'anic description of paradise as impossi-ble, requiring an unending multiplication of locations in the afterlife for devout Muslims. Torquemada also offered a Thomistic view of the risen body as incapable not just of sexual pleasure but a free from worldly suffering.
\end{abstract}

\section{Keywords}

Juan de Torquemada; Nicholas of Cusa; Pius II; paradise; Islamic belief; Christian polemics against Islam

By the mid-fifteenth century, the Ottoman Turks were a serious threat to Western Christendom, militarily, religiously and culturally. The Turks were Muslims and, from a Western viewpoint, barbarians. ${ }^{1}$ Moreover, the religion they embraced, Islam, was seen as a threat to Christian values, promising

${ }^{1}$ Bisaha, N., «'New Barbarians' or Worthy Adversaries? Humanist Constructs of the Ottoman Turks in Fifteenth-Century Italy», in D.R. Blanks and M. Frassetto (eds.), Western Views of Islam in Medieval and Early Modern Europe. Perception of the Other, New York, St. Martin's Press, 1999, pp. 185-205; Meserve, M., Empires of Islam in Renaissance Historical Thought, Cambridge, MA, Harvard University Press, 2008. 
believers a paradise of delights. ${ }^{2}$ Thus apologists for Western European values felt compelled, as we shall see, to denounce the Islamic view of the afterlife of luxury and sexual indulgence. They also argued, whether in a rhetorical or a theological mode, that the Christian idea of the afterlife was superior, offering intellectual pleasure and a glorified body, much better than bodily pleasure.

In 1453 the forces of Sultan Mehmed II captured Constantinople, which became their capital, Istanbul. Aeneas Sylvius Piccolomini described this capture as "another death for Homer», as well as a threat to Western Christendom. ${ }^{3}$ The Ottoman sultan did not stop there, expanding through the Balkans until forced by a crusading host to retreat from Belgrade in $1456 .{ }^{4}$ This is where matters stood when Callixtus III died in 1458, leaving the leadership of Christendom in doubt. Aeneas Sylvius Piccolomini was elected to succeed him as Pius II. Some cardinals resisted Piccolomini's candidacy on the grounds that his ill health would hinder the conduct of a crusade to turn back the Turks. ${ }^{5}$ Perhaps because of the opposition to his candidacy, Pius II made the crusade a large part of his papal policy. ${ }^{6}$

The first step toward a crusade was the effort to mobilize the princes of Europe at the Congress of Mantua (1459). The princes, who had their own agendas, greeted the pope's policy, presented in one of his Latin orations, with

${ }^{2}$ Southern, R.W., Western Views of Islam in the Middle Ages, Cambridge, MA, Harvard University Press, 1962, pp. 27-32, 37-42; Daniel, N., Islam and the West. The Making of an Image, rev. ed., Oxford, One World, 1993, pp. 302-337.

${ }^{3}$ Runciman, S., The Fall of Constantinople 1453, repr. ed., Cambridge, Cambridge University Press, 1990; Babinger, F., Mehmed the Conqueror and His Times, trans. R. Manheim, Princeton, NJ, Princeton University Press, 1978, pp. 87-101. Izbicki, T.M., Christianson G., Krey Ph. (eds.), Reject Aeneas, Accept Pius. Selected Letters of Aeneas Sylvius Piccolomini (Pope Pius II), Washington, DC, Catholic University of America Press, 2006, pp. 306-318.

${ }^{4}$ Inalcik, H., «The Ottoman Turks and the Crusades, 1451-1522», in ed. H.W. Hazard and N.P. Zacour (eds), A History of the Crusade, vol. 6, Madison, WI, University of Wisconsin Press, 1989, pp. 311-353 at pp. 322-324; Babinger, Mehmed the Conqueror and His Times, pp. 137-150.

${ }^{5}$ For Piccolomini's presentation of his success, see Pius II, Commentaries, trans. M. Meserve and M. Simonetta, vol. 1, Cambridge, MA, Harvard University Press, 2003, pp. 176-203. A more wide-ranging analysis is presented in Baldi, B., Pio II e la trasformazioni dell'Europa (1457-1464), Milano, Unicopoli, 2006, pp. 3-28. On Torquemada, see Izbicki, T.M., Protector of the Faith. Cardinal Johannes de Turrecremata and the Defense of the Institutional Church, Washington, DC, Catholic University of America Press, 1981.

${ }^{6}$ O'Brien, E., The Commentaries of Pope Pius II (1458-1464) and the Crises of the FifteenthCentury Papacy, Toronto, University of Toronto Press, 2015; von Martels, Z., «More Matter and Less Art'. Aeneas Sylvius Piccolomini and the Delicate Balance between Eloquent Words and Deeds», in von Martels, Z., and A. Vanderjagt (eds.), Pius II, «El Piu Expeditivo Pontefice», Leiden, Brill, 2003, pp. 205-227. 
little enthusiasm. Pius later complained that most of his cardinals were not supportive. Among the cardinals, a Greek (Bessarion of Nicaea) and a Spaniard (Juan de Torquemada), once his opponents in the conclave, did back him. ${ }^{7}$ The remainder of Pius' pontificate would see efforts to win the religious conflict by warfare, propaganda or religious diplomacy. ${ }^{8}$

The chief crusade apologists in this period were Pius himself, Juan de Torquemada, and Nicholas of Cusa. They wrote about Islam in different ways with different outcomes in mind, although, as will be shown, they shared common ground. Pius II was a man of letters, master of a pungent Latin style. He wrote a letter, addressed to Mehmed II with which he may have hoped to persuade the sultan to convert. ${ }^{9}$ It is more likely that the pope was engaging in crusade polemic, hoping to shame Europe's princes to give up selfish advantage in the cause of Christendom. Whatever his motivation, Pius left the work unpublished at his death in 1464. The text itself is a mixture of persuasion and diatribe, possibly reflecting its author's mixed motives or a desire to show Mehmed the advantages of converting and the disadvantages of remaining a Muslim. ${ }^{10}$

At the Council of Basel, Cusanus shared study of Islam with the Castilian theologian John of Segovia, who commissioned a trilingual translation of the

${ }^{7}$ Russell, J.G., Diplomats at Work. Three Renaissance Studies, Stroud, Alan Sutton, 1992, pp. 51-93; Baldi, Pio II, pp. 147-170. Bessarion and Torquemada had resisted Aeneas' election because of their desire for a healthy crusading pope; see Pius II, Commentaries, vol. 1, pp. 182-183, 194-197. On their support of the crusade, see Pius II, Commentaries, vol. 2, Cambridge, MA, Harvard University Press, 2007, pp. 10-11.

${ }^{8}$ Pius' pontificate was not entirely devoted to opposing the Turks. He also was involved in Italian politics and trying to secure revocation of the French Pragmatic Sanction of Bourges (1439), which imposed reforms on the Church in the interest of royal power. Baldi, Pio II, pp. 107-146; Lewis, P.S., «The Concordat of 1472. An Essay on the Relations between Louis XI and Sixtus IV», in Lewis, P.S., (ed.), The Recovery of France in the Fifteenth Century, New York, Harper and Row, 1972, pp. 102-184.

${ }^{9}$ Mehmed was known to have devotion to Mary; see George-Tvrtković, R., Christians, Muslims, and Mary. A History, Mahwah, NJ, Paulist Press, 2018, p. 48; George-Tvrtković, «Bridge or Barrier? Mary and Islam in William of Tripoli and Nicholas of Cusa», Medieval Encounters, 22 (2016), pp. 307-325. Cusanus urged Christians to pray for the sultan's conversion; see George-Tvrtković, R., Christians, Muslims, and Mary, op. cit., p. 104.

${ }^{10}$ Aeneas Sylvius Piccolomini, Epistola ad Mahomatem II (Epistle to Mohammed II), ed. and trans. A.R. Baca, New York, Peter Lang, 1990. Mercan, O., Constructing a Self-Image in the Image of the Other. Political and Religious Interpretation of Pope Pius II's Letter to Mehmed II (1461), Budapest, Central European University, 2008; Bisaha, N., «Pope Pius II's Letter to Sultan Mehmed II. A Reexamination», Crusades, 1 (2002), pp. 183-200. 
Qur'an (now lost). ${ }^{11}$ When Cusanus left Basel, he voyaged to Constantinople in support of Eugenius IV's council of union with the Greeks. In Pera he was shown an Arabic text owned by the Franciscans, and he found a copy of Robert of Ketton's Latin text at the Dominican convent. After returning to Italy, Cusanus would annotate two copies of the Qur'an in hope of better understanding Islam. ${ }^{12}$ After the fall of Constantinople, Nicholas would hypothesize a celestial gathering which would find common ground among the world's religions. ${ }^{13}$ Later, Cusanus would employ his study of Islam in a detailed exegetical study of the Qur'an, the Cribratio Alchorani, which he addressed to Pius II, saying he hoped to demonstrate the truth of the Gospel from the Qur'an. ${ }^{14}$

The Cribratio was not the first curial writing against Islam written during Pius' pontificate. In the preface of the Cribratio, Nicholas mentioned Juan de Torquemada, the Cardinal of San Sisto, "who with cogent reasons refutes the heresies and the errors of Muhammad.» Torquemada too addressed his tract, Tractatus contra principales errores perfidi Machometi, to Pius II. Completed in 1459, it must be understood in the context of the failed Congress of Mantua. Torquemada referred to this meeting as a forthcoming dieta located near enough to the Alps for the Ultramontane princes to be represented there: «Many other places being inconvenient to accommodate it, the diet will be celebrated at a time in a certain place near the Ultramontane provinces, with the coming there of the princes to whom the protection of the Church was assigned long ago ${ }^{15} \mathrm{He}$ described the savaging of Christian peoples «disturbed,

${ }^{11}$ Roth, U., «Juan of Segovia's Translation of the Qur'ān» al-Qantara. Revista de estudios árabes, 35 (2014), pp. 555-578.

${ }^{12}$ Martínez Gázquez, J., «Nicolás de Cusa y las glosas del ms. Vat. Lat. 4071 para la redacción de la Cribratio Alkorani», Bulletí de la Real Acadèmia de Bones Lletres de Barcelona, 54 (2013-2014 [2016]), pp. 103-116; Martínez Gázquez, «A New Set of Glosses to the Latin Qur'an Made by Nicholas of Cusa (MS Vat. Lat. 4071», Medieval Encounters, 21 (2015), pp. 295-309; Biechler, J.E., «Three Manuscripts on Islam from the Library of Nicholas of Cusa», Manuscripta, 27 (1983), pp. 91-100.

${ }^{13}$ Nicolai de Cusa Opera Omnia, vol. 7, De pace fidei; Hopkins, J. (trans.), Complete Philosophical and Theological Treatises of Nicholas of Cusa, 2 vols., Minneapolis, Banning 2010, vol. 1, pp. 631-676; Nicholas of Cusa on Interreligious Harmony, ed. J.E. Biechler and H.L. Bond, Lewiston, Edwin Mellen, 1990.

${ }^{14}$ Martínez Gázquez, «A New Set of Glosses to the Latin Qur'an», op. cit., p. 299. On the dedication of the Cribratio, see Nicolai de Cusa opera omnia, vol. 8, pp. 5-6; Hopkins, Complete Philosophical and Theological Treatises of Nicholas of Cusa, op. cit., vol. 2, pp. 965-966.

${ }^{15}$ Madrid Universidad Complutense E3 C4 N6, fol. 57r-150r at fol. 57r, «Aliisque incomodis multis certo loco propinquo ultramontaneis prouinciis pro tempore acomodare. Ubi aduenientibus christianis principibus quibus tutella ecclesie diutius est consignata celebraretur dieta.» 
molested» by the Turks in hope of mobilizing lay support for the crusade ${ }^{16}$ The cardinal also hoped that a crusade would promote the internal peace of Christendom. ${ }^{17}$

Like many other polemics against Islam, this tract depended on the Christian sources and a Latin Qur'an, in this case probably the less-known translation by Mark of Toledo. Torquemada made direct use of this text, as can be demonstrated from his reference to "chapter twenty-four» concerning the unwillingness of angels to reverence men because they were born of fire but humanity from mud..$^{18}$ The author's approach, as noted above, was relentlessly systematic; and its tone was harsh, frequently calling the Prophet «bestial». Taking up past terminology for Muslims, the tract refers to the Turks as Saracens. ${ }^{19}$ Toward the end of his tract, Torquemada urged the princes of Europe to take up the cross and defeat the Ottomans. ${ }^{20}$

Torquemada had not previously focused on Islam in his writings. His previous targets included not just conciliarists and Hussites but the old Christians of Toledo who had attacked Jewish converts as incapable of being true Christians. ${ }^{21}$ Torquemada would not write another tract on Islam after

${ }^{16}$ The dedication to Pius II speaks in general terms of the Turks persecuting Christians, but there is no mention of Constantinople or other Turkish conquests; see Madrid Universidad Complutense E3 C4 N6, fol. 57r, «per diuersas orbis prouincias Christianum populum Turchus perturbat \& infestat ut demolire eum festinet» The text goes on to speak of Ottoman territorial ambitions. For a suggestion that Pius II commissioned the tract, see Echeveria, A., The Fortress of Faith. The Attitudes toward Muslims in Fifteenth-Century Spain, Leiden, Brill, 1999, p. 45.

${ }^{17}$ Madrid Universidad Complutense E3 C4 N6, fol. 57v. Torquemada urged Pius to light a flame not just to defend the faith, but «Ad pacem et quitem populi christiani incencederit»; see fol. 57r.

${ }^{18}$ Madrid Universidad Complutense E3 C4 N6, fol. 111v. Burman, Reading the Qur'ān, op. cit., pp. 17-18, 23-24, 40-41, 44, 123-133. The author owes his reference to Mark's translation to Rita George-Tvrtković.

${ }^{19}$ Adeva, I., "Juan de Torquemada y su Tractatus contra principales errores perfidi Machometi et Turcorum sive Saracenorum (1459)», Anuario de historia de la iglesia, 16 (2007), pp. 195-208; Cantarino, V., «Juan de Torquemada's Crusade against Islam», in B. Lewis and F. Newöhner (eds.), Religionsgespräche im Mittelalter, Wiesbaden, Harrassowitz, 1992, pp. 237-250. The text survives in fourteen manuscripts and four early editions; see Kaeppeli, T., Scriptores Ordinis Praedicatorum medii aevi, vol. 3, Roma, Ad S. Sabinae, 1980, pp. 38-39 no. 2732.

${ }^{20}$ Madrid Universidad Complutense E3 C4 N6, fol. 145v-149v.

${ }^{21}$ Juan de Torquemada, Tractatus contra Madianitas et Ismaelitas (Defensa de los Judios Conversos), ed. N. Lopez Martinez and V. Proaño Gil, Burgos, Hijos de S. Rodríguez, 1957. Izbicki, T.M., «Juan de Torquemada's Defense of the Conversos», Catholic Historical Review, 85 (1999), pp. 195-207. 
1459, but he did write two years later to instruct the Bogomils of Bosnia in the true faith. This tract fit into Pope Pius' efforts to win the Bosnians to orthodoxy just as they were in danger of being overrun by the Ottomans. However, it makes no mention of the Ottoman threat. Despite this silence about the Turkish menace, Bosnia's fortunes turned for the worst, with Mehmed II overrunning the kingdom two years later. ${ }^{22}$

However, in his last years, during the pontificate of Paul II, Torquemada would write a collection of questions based on Gospel readings from the liturgical lectionary. Treating the celestial banquet described in Luke 14, he argued that the feast would be spiritual, not corporeal. In this context he criticized the Epicureans and Muhammad for embracing bodily pleasures. This he contrasted not just with Christian belief, but with the opinions of most philosophers: «Therefore, it is necessary to posit that blessedness is in the soul according to the philosophers, although some, like the Epicureans and Muhammad posit blessedness in the good things of the body». ${ }^{23}$

Once again, the Prophet was denounced as «stupid», the life he promised as «bestial», "not of human beings but of sheep». Torquemada cited Aristotle's Nicomachean Ethics in support of this argument. ${ }^{24}$ The Cardinal of San Sisto cut this polemical excursus short with a reference to his 1459 work, «We reproved this error in our tract against Muhammad». ${ }^{25}$

The tract by Torquemada opened with a diatribe against the character traits of Muhammad. One of these was carnality, a trait the opposite of Christian

${ }^{22}$ Juan de Torquemada, Symbolum pro informatione Manichaeorum (el Bogomilismo en Bosnia), ed. N. Lopez Martinez and V. Proaño Gil, Burgos, Hijos de S. Rodríguez, 1958. Torquemada referred to each Manichaean error of the Bosnians as a «stupidity» (stultitia).

${ }^{23}$ Juan de Torquemada, Quaestiones evangeliorum tam de tempore quam de sanctis, Nürnberg, Creusner, 1478, in dominica secunda post Pentecostem q. 1, «Vnde necesse est beatitudinem ponere in bonis anime etiam secundum philosophos. quod autem aliqui vt epicuri \& machometus in bonis corporis beatitudinem posuerunt» (emphasis mine here and in the next two notes).

${ }^{24}$ Juan de Torquemada, Quaestiones evangeliorum tam de tempore quam de sanctis, loc. cit., «Respondeo dicendum. error fuit stulti machometi qui posuit felicitatem \& beatitudinem futuram in corporalibus delectationibus ciborum \& potum et venereorum. qui error non solum apud cristiane religionis cultatores. sed etiam apud gentiles philosophos qui beatitudinem nouerunt in operibus intellectiue partes consistere iudicatur bestialis. vitam huiusmodi voluptuosam non hominum sed pecudum esse asserentes. vt patet i. ethicorum.» In response to an argument he was refuting, Torquemada described such physical pleasures as befitting pigs (porcis).

${ }^{25}$ Juan de Torquemada, Quaestiones evangeliorum tam de tempore quam de sanctis, loc. cit., «Multis autem rationibus reprobauimus hunc errorem in tractatu nostro contra machomentum nunc breuiter sufficient». 
emphases on asceticism and the glorified body, not just of the risen Christ but of the saved when they rose at the Second Coming. ${ }^{26}$ This trait Torquemada connected to Muhammad's own nature: «For he was luxurious and inflamed by the ardor of lust more than other men of the eastern region» ${ }^{27}$ Torquemada went on to say that Muhammad claimed permission to sleep with all women (concubere posset cum omnibus mulieribus), and he noted that the Prophet had fifteen wives and two «maids» (ancillas), probably meaning concubines. ${ }^{28}$ The Qur'an (nephariam scripturam) he described as made up from Jewish and heretical sources «in his barbarous way» (barbaro illo suo modo). ${ }^{29}$

In Muhammad's «law» the obstacles to luxury and voluptuousness were removed. This, in turn, helped him expand the borders of his «sect»:

The fourth proof was because he gave a carnal law, relaxing the restraint on luxury and voluptuousness, which carnal men, corrupted in the mind, freely embraced. And so, it is obvious that he was most studious in expanding his sect and doing wicked things. ${ }^{30}$

(An irony of this polemic is that, for all its criticisms of Muslim carnality, it treats the Prophet's rejection of wine drinking as one of his errors. ${ }^{31}$ )

Torquemada dealt with this charge of carnality more than once, claiming that Muhammad sanctioned «adultery» and sins against nature, while offering his followers a paradise full of fleshly delights. The section on adultery actual focuses more on fornication, making war captives into concubines and

${ }^{26}$ The emphasis on the glorified bodies of the saved was reached in lively debates in the medieval West; see Bynum, C.W. The Resurrection of the Body in Western Christianity, 2001336, New York, Columbia University Press, 1995. The glorified body of Christ was believed to be present in the Eucharist on many altars at the same time; see Adams, M.M., Some Later Medieval Theories of the Eucharist. Thomas Aquinas, Giles of Rome, Duns Scotus and William Ockham, Oxford, Oxford University Press, 2010.

${ }^{27}$ Madrid Universidad Complutense E3 C4 N6, fol. 59v, «Nam fuit luxuriosus et libidinis ardore succensus super omnes homines orientalis regionis.» Torquemada's described this and other «traits» of Muhammad in terms derived from the book of Revelation.

${ }^{28}$ Madrid Universidad Complutense E3 C4 N6, fol. 59v.

${ }^{29}$ Madrid Universidad Complutense E3 C4 N6, fol. 61r.

${ }^{30}$ Madrid Universidad Complutense E3 C4 N6, fol. 61v-62r, «Quarta cautella fuit quia legem dedit carnalem laxans frena luxurie et voluptati quam homines carnales mente corrupti libenter amplecturi. Et ita patet qualiter in dilacione sue secte et malis operandis fuit studiosissimus.»

${ }^{31}$ Madrid Universidad Complutense E3 C4 N6, fol. 130v-132v. Cusanus also noted this prohibition; see Martínez Gázquez, «A New Set of Glosses to the Latin Qur’an», op. cit., p. 306. 
polygamy. Torquemada quoted «chapter 32» of the Qur'an as saying: «Observe chastity unless with one's own wives or subjects or serving maids».32 The cardinal argued that Christianity had a better model of family, supporting not pleasure but procreation and raising of children (procreanda et educanda). ${ }^{33}$ Muhammad, he said, "placed his pleasure in intercourse». Thus, he permitted having concubines, which Torquemada said was "contrary to the law of nature", since a man went to bed with women not bound to him by marriage. ${ }^{34}$ Looking at the evidence of polygamy in the Bible, the cardinal quoted Aquinas as saying these men treated their concubines «with marital affection» (uxoris affectu); therefore, they did not endure «the brutal liberty which Muhammad salaciously conceded to his followers». ${ }^{35}$ Torquemada was vague about what he meant by sins against nature, except the claimed that the Prophet said you could treat your women "as you wish» (ut vultis). However, he cited the punishment of the men of Sodom, «the worst of men» (pessimi homines) without further explanation of their fatal actions. ${ }^{36}$

Torquemada's criticism of the Islamic view of paradise was much more extensive, and it reached beyond sex to a wider view of the carnal pleasure promised to Muslims. It encompassed food and drink, clothing and non-sexual pleasurable acts. His opening summary of these promises bears quoting: "In another life, after the resurrection, there will be use of foods, clothing and venereal pleasures, as he often says in his book». ${ }^{37}$ This attitude he compared with heretics denounced by Augustine for their belief that the risen will enjoy unlimited "carnal» foods and drinks (cibis et potibus carnalibus)..$^{38}$ In contradiction, Torquemada cited Jesus' reply to the Sadducees (Matthew 22), that

${ }^{32}$ Madrid Universidad Complutense E3 C4 N6, fol. 122r, «Castitatem nisi cum propriis uxoribus seruate aut sibi subiectis et ancillis obseruientibus.»

${ }^{33}$ Madrid Universidad Complutense E3 C4 N6, fol. 122v. Torquemada cited book eight of Aristotle's Ethics as an obligation of parents.

${ }^{34}$ Madrid Universidad Complutense E3 C4 N6, fol. 122v, «posuit delectationem in coitu... patet quod contra legem nature sit accedere ad concubinam non coniunctam sibi matrimonio que concubina vocatur.»

${ }^{35}$ Madrid Universidad Complutense E3 C4 N6, fol. 123r, «Unde in illis non fuit brutalis libertas quam Machometus concessit suis.»

${ }^{36}$ Madrid Universidad Complutense E3 C4 N6, fol. 123r-v. One of Cusanus' glosses on the Qur'an cites Riccoldo da Monte Croce and Robert of Ketton as understanding such passages to permit sodomizing women; see Martínez Gázquez, «A New Set of Glosses to the Latin Qur'an», op. cit., p. 302 n. 16.

37 Madrid Universidad Complutense E3 C4 N6, fol. 123v, «in alia uita post resurrectionem usum esse ciborum uestimentorum et uenereorum sicit sepe in suo libro ostendit.»

${ }^{38}$ Madrid Universidad Complutense E3 C4 N6, fol. 123v, citing De civitate Dei, book 20 chapter 7. 
after the resurrection there would neither be marrying of men nor giving in marriage of women. «Human beings will not rise to a mortal life, using food and sex, but they would be like the angels». ${ }^{39}$ Eating and having sex belonged to the corruptible present life, not to the incorruptible future life. Food would not need to be ingested or digested. ${ }^{40}$

Likewise, sex would not be necessary in paradise. Sex, in Torquemada's polemic, was for procreation. In paradise, there would be no need to procreate. In a literal-minded slap at Islam, he considered what would happen if procreation occurred after the resurrection of the dead. The cardinal argued that, with death no longer holding sway over humanity, procreation would cause paradise to become overpopulated. "In a short time, it would be necessary for many to leave paradise», perhaps to some new region created for them, a process which would continue ad infinitum..$^{41}$ Furthermore, there would be no need to increase the population. This left unceasing sexual delight as a part of «the ultimate reward» (ultima remuneratione) Muhammad promised his followers, an idea Torquemada found in the Doctrina Machometti, a work included in the Toledo corpus. ${ }^{42}$ His opinion on the role of pleasurable acts in life was that nature instituted them so that animals would not cease performing necessary labors. ${ }^{43}$

Torquemada's polemic included a list of three pleasures the Prophet was not ashamed to promise to his followers. All these he rejected as carnal and filthy: «Through the whole of his Qur'an, he was not ashamed to promise carnal and filthy happiness in another life. $\rangle^{44}$ Although we most often focus on the sexual aspects of Muhammad's paradise, the cardinal's list of the Prophet's errors is longer. These errors include fine food and precious clothing.$^{45}$ Only in

${ }^{39}$ Madrid Universidad Complutense E3 C4 N6, fol. 123v, «quia homines non resurgent ad uitam mortalem cibis et uenereis utentes sed erunt sicut angeli.» He added a quotation from the Ordinary Gloss they would enjoy the divine vision sine labore et corruptione.

${ }^{40}$ Madrid Universidad Complutense E3 C4 N6, fol. $124 \mathrm{r}-\mathrm{v}$.

${ }^{41}$ Madrid Universidad Complutense E3 C4 N6, fol. 124v, «quare breui tempore necesse habebit exire magna pars populi illius de paradiso. Et creari necesse erit eis regionem aliam ad habitacionem et non unam solam sed etiam infinitas.» On the abolition of death, which was brought on by Adam's sin; see op. cit., fol. $125 \mathrm{r}$.

${ }^{42}$ Madrid Universidad Complutense E3 C4 N6, fol. 124v, «ne aliqua delectatio in ultima remuneratione hominis desit sicut expresse dicit Machometus in libro de sua doctrina.»

${ }^{43}$ Madrid Universidad Complutense E3 C4 N6, fol. 125r.

${ }^{44}$ Madrid Universidad Complutense E3 C4 N6, fol. 125v, «per totum suum Alchoranum carnalem et spurcissimum felicitatem sue genti in alia vita promittere non pudit.»

${ }^{45}$ Madrid Universidad Complutense E3 C4 N6, fol. 125v, 126v. in the latter place the cardinal treated the promise of fine goods in detail as a «better» form of the pleasures of this life. 
third place did the cardinal list sexual delights found with concubines and other women. ${ }^{46}$ One of his more rhetorical arguments offered a treatment of the numerous things necessary for the human pleasures the Prophet promised, even including horses for jousting. ${ }^{47}$ Torquemada accused Muhammad of following the Epicureans (epicurios) in a belief in such human felicity. Felicity, he argued, lay instead «in the act of the superior, intellective part, with respect to its most noble object, which is God». ${ }^{48}$ The vision of God, Torquemada wrote, was the supreme happiness of men and angels. ${ }^{49}$ This pertained to the intellect, the most noble aspect of humanity. ${ }^{50}$

What Torquemada was addressing in his critique of Islam was not just concerned with denying the risen bodies the pleasures of bed and board ${ }^{51} \mathrm{He}$ was advancing a theological opinion about the glorified bodies of the saved. This required that he consider, first of all, Christ's risen body. Its perfection was such that no alimentation was needed. Christ ate «not because of necessity but to demonstrate His resurrection $» .^{52}$ (In a commentary on Psalm twenty-nine, in another work addressed to Pius II, Torquemada had Jesus say that He was raised «in a body glorified and immortal» [glorioso et immortali]. ${ }^{53}$ ) Following the opinions of earlier Scholastics, ${ }^{54}$ Torquemada reminded his readers that the faithful, sharing their Savior's triumph, also would have glorified bodies. These bodies would have four qualities, none related to their bodily life before death

${ }^{46}$ Madrid Universidad Complutense E3 C4 N6, fol. 125v.

${ }^{47}$ Madrid Universidad Complutense E3 C4 N6, fol, 129v-130v.

${ }^{48}$ Madrid Universidad Complutense E3 C4 N6, fol. 125r,-v, «sed in actu superioris partis intellectiue in respectu nobilissimi obiecti quod est deus.» A list of biblical proofs follows.

${ }^{49}$ Madrid Universidad Complutense E3 C4 N6, fol. 126r, «et hec visio diuinitatis est summa Felicitas hominum et angelorum.»

${ }^{50}$ Madrid Universidad Complutense E3 C4 N6, fol. 127r, «sed id quod nobilissimum in eo quod est intellectus.» Torquemada followed this with dismissal of carnal delights as inferior.

${ }^{51}$ The cardinal reminded his readers that the Prophet was offering pleasures related to sustaining mortal life; see Madrid Universidad Complutense E3 C4 N6, fol. 128r.

${ }^{52}$ Madrid Universidad Complutense E3 C4 N6, fol. 125v, «quem christus post resurrectionem non propter neccessitatem sed ad monstrandum sue resurrectionis.» In a question on the gospel for the second Sunday of Advent, Torquemada repeated an opinion of Thomas Aquinas that, at the Second Coming, both the saved and the damned will see the glorified body, but the latter will suffer when seeing it in Torquemada, Quaestiones evangeliorum, Second Advent q. 2, citing Aquinas on the Sentences Lib. IV Dist. 48 q. 1 art. 2.

${ }^{53}$ Juan de Torquemada, Expositio breuis et vtilis super toto psalterio, Mainz, Schaeffer, 1474, Psalmus xxix.

${ }^{54}$ Bynum, Resurrection of the Body, pp. 210-211, 253-254. 
and resurrection, just as the saints received these gifts: «The learned [say there will be] something like four gifts of the glory of the bodies of the saints, which are clarity, impassibility, subtlety and agility». The resurrection of the human race would involve raising both men and women with all their bodily parts, although not for use in procreation. ${ }^{55}$

The issue of a carnal paradise does not loom as large in the writings of Cusanus and Pius as it does in Torquemada's tract, although both addressed it in the context of the crusade. Evidence for Cusanus' support of the anti-Turkish crusade following 1453 is sparse. He preached in the diocese of Brixen on the occasions of two processions ordered by Callixtus III invoking divine aid against the Turks. Two of these, in August of 1456, celebrated the triumph of Christian arms at Belgrade..$^{56}$ The third, preached in October of the same year, said the Turk wanted to exterminate any power contrary to his. ${ }^{57}$ Cusanus was at Mantua briefly, probably before taking his place as papal vicar in temporalibus for Rome in 1459. While there, he gave a warm welcome to Albert Achilles of Brandenburg, thanking him for his willingness to support the crusade. ${ }^{58}$ This may have encouraged the pope to commission Cusanus to write on Islam, the result of which was the Cribratio. We do not know how Pius reacted to a text less polemical than exegetical, seeking to find common ground, however limited, with Muslims.

The Cribratio treats the Islamic view of paradise at the end of book two, following extensive discussions of Christology and heaven..$^{59}$ Cusanus has a

${ }^{55}$ Madrid Universidad Complutense E3 C4 N6, fol. 130v, «beatitudo enim corporis humani non in hiis consistit. si ex redundancia beatitudinis anime in ipsum corpus, ipsum glorificabitur, cuius glorificacio quattuor continebit, dotes tamquam quattuor partes glorie corporum sanctorum, que sunt claritas, impassibilitas, subtilitas et agilitas.... Ceterum sexum et membrorum varietas post resurrectionem non erit frustra cum sit ad nature humane perfectionem reintegrandam in specie et indiuiduo quamuis animales operaciones desint» [translation mine].

${ }^{56}$ Sermones 140, 241 and 248 in Nicolai de Cusa opera omnia, vol. 19, pp. 228-242, 298-306. Cusanus added a note to a sermon in the Brixen years identifying Mohammed as born in Corozain, a place legend identified with the birth of the Antichrist; see Sermo 210 (1455), op. cit., vol. 19 , p. 39.

${ }^{57}$ Sermo 248 in Nicolai de Cusa opera omnia, vol. 19, 298.

${ }^{58}$ Pius II, Commentaries, vol. 2, pp. 190-193. For Cusanus' role in Rome in Pius' absence, see Meuthen, E., Die letzten Jahre des Nikolaus von Kues. Biographische Untersuchungen nach neuen Quellen, Köln, Westdeutscher Verlag, 1958, pp. 28-52.

${ }^{59}$ Book two was concerned with heaven in general, not just with the Islamic on paradise; see Costigliolo, M., The Western Perception of Islam between the Middle Ages and the Renaissance. The Work of Nicholas of Cusa, Eugene, OR, Pickwick, 2017, pp. 91-93. Cusanus drew on Riccoldo da Montecroce and William of Tripoli in his composition of this work; 
hypothetical Arab say Islam promises «the fulfillment of all desires» to «believers and keepers of the law». This Arab adds that the Gospel only promises «intellectual happiness». Cusanus replied with a claim that intellectual and invisible things are both eternal and superior to physical things. ${ }^{60}$ Nicholas partially excused this «inferior» vision of the afterlife by saying the Prophet was persuading uneducated Arabs. The believers were promised a life better than the present one. Sura 51 was quoted on believers possessing «the most beautiful places in Paradise». ${ }^{61}$ This promise of sensible things included "very lovely and very pure women», as well as pure water and varied produce. Seeking a favorable approach to such texts, Cusanus said the goods of the future age are superior to those of the present life. ${ }^{62}$ He also cited Avicenna as dismissing Muhammad's view of paradise in favor of intellectual happiness described by «the wise». Then Nicholas concluded that the Qur'an occasionally promises «knowledge of God and Wisdom» to the truly wise. This wisdom Cusanus identified with the Son of God, Christ. ${ }^{63}$ In the following chapter, Cusanus engaged in a polemic against the promises of maidens and copulation found in passages like Sura 87. He also noted the acceptance of polygamy by the Prophet, who said it was according to the divine will. ${ }^{64}$ The second book

see Costigliolo, Western Perception of Islam., pp. 85-91; George-Tvrtković, Christians, Muslims and Mary, op. cit., pp. 65.

${ }^{60}$ Hopkins, Complete Philosophical and Theological Treatises of Nicholas of Cusa, vol. 2, p. 1043; Nicolai de Cusa opera omnia, vol. 8, p. 121, «Diceret Arabicus aliquis: Remota sunt illa, quae de paradiso in Alkorano leguntur, et ea, quae evangelium promisit. Alkoranus enim decideriorum omnium complementum credulis et legem servantibus promittit describitur illa desideria, quae communiter appetuntur per voluptuosos, sed evangelium solum promittit intellectualem felicitatem, quae est in visione intellectuuali et scientia, sapientia et cognition.» Sermo 240 in Nicolai de Cusa opera omnia, vol. 19, p. 229, says that Islam promises a false paradise.

${ }^{61}$ Hopkins, Complete Philosophical and Theological Treatises of Nicholas of Cusa, vol. 2, p. 1044; Nicolai de Cusa opera omnia, vol. 8, p. 121, «Respondemus semper nobis apparuisse tantum inter paradisum Mahumeti et Christi interesse, quantum inter sensibilia et intellectualia aut inter visibilia, quae sunt temporalia et invisibilia, quae sunt aeterna.» Costigliolo, Western Perception of Islam, pp. 115-116.

${ }^{62}$ Hopkins, Complete Philosophical and Theological Treatises of Nicholas of Cusa, vol. 2, p. 1044-1045; Nicolai de Cusa opera omnia, vol. 8, pp. 122-123.

${ }^{63}$ Hopkins, Complete Philosophical and Theological Treatises of Nicholas of Cusa, vol. 2, p. 1045; Nicolai de Cusa opera omnia, vol. 8, p. 124, «Sed Alkoranus, licet minus extense, perfectam felicitatem sapientum ponat in notitia dei et sapientiae, quae est filius dei secundum praemissa, quemadmodum et evangelium ex Christi perfectissima doctrina.»

${ }^{64}$ Hopkins, Complete Philosophical and Theological Treatises of Nicholas of Cusa, vol. 2, pp. 1046-1047; Nicolai de Cusa opera omnia, vol. 8, pp. 126-127. Cusanus' glosses on Qur'an manuscripts presented an old argument that Muhammad forbade fornication in temples but 
concludes with questions addressed to Mohammed, asking why he spoke against the Scriptures, teaching a new law, when he knew the truth of the Gospel. What Muhammad offered instead of the «light of the gospel» was appealing to «bestiality and animality» in his followers. However, God permitted an admixture of light to reach the wise through this channel. Book two of the Cribratio ends with a dismissal of the Prophet's teaching as offensive, especially to the wise. ${ }^{65}$

Different opinions exist not just about the purpose of Pius II's letter to Mehmed II, but about the sources on which he drew. Both Torquemada and Cusanus have been identified as sources. ${ }^{66}$ Pius' rhetoric differs from the approach of either author, being neither Scholastic nor exegetical. Moreover, the mixture of persuasion and polemic in the letter complicates the picture, unless one posits that the pope drew on both authors depending on where his argument would turn next. Since the letter never was sent to Istanbul or divulged in the West in Pius' lifetime, consequently receiving no criticism by Muslims of Christians, some doubt must remain in this matter.

The letter of Pius is well-known for its promises to Mehmed II, saying baptism would bring him everything he sought by force of arms, including the loyalty of his Christian subjects. ${ }^{67}$ Pius added examples of rulers who prospered after converting. Among them are Constantine and Clovis. ${ }^{68}$ The pontiff added a philosophical turn to his text by citing the ideas of the Peripatetics and Stoics, especially the latter, on the elevation of the soul as the greatest human

permits it in paradise; see Martínez Gázquez, «A New Set of Glosses to the Latin Qur'an», op. cit., pp. 304-305.

${ }^{65}$ Hopkins, Complete Philosophical and Theological Treatises of Nicholas of Cusa, op. cit., vol. 2, pp. 1047-1048; Nicolai de Cusa opera omnia, vol. 8, p. 128, «Tamen omnipotens deus inter omnia illa spurca et vana et sapientibus etiam Arabum abominabilia talia enim inseri voluit, in quibus evangelicus splendor sic lateret occultatus, quod sapientibus diligenti studio quaesitus se ipsum manifestaret.» Cusanus, loc. cit., said the wise found the Prophet's teaching «obscurum, inordinatum, tenebrosum, mortiferum et intellectuali naturae abominabile, licet bestialitati et animalitati, quae est de hoc sensibili mundo, sapida videatur.»

${ }^{66}$ Babinger, F., «Pio II e l'Oriente maomettano», in Enea Silvio Piccolomini, Papa Pio II, in Maffei, D. (ed.), Enea Silvio Piccolomini, Papa Pio II, Siena, Accademia Senese degli Intronati, 1968, 1-13. Gaeta, F., «Alcune osservazione sulla prima redazione della lettera a Maometto», in op. cit., pp. 177-187; Costigliolo, Western Perception of Islam, op. cit., 140-141.

${ }^{67}$ Piccolomini, Epistola ad Mahomatem II (Epistle to Mohammed II), Einleitung, kritische Edition, Ubersetzung und ed. R. Glei, Trier, WVT, Wiss. Verl. Trier, 2001, pp. 17-21, 24, 121125,129 . Cusanus offered some of the same arguments; see George-Tvrtković, Christians, Muslims and Mary, op. cit., pp. 65-66.

${ }^{68}$ Piccolomini, Epistola ad Mahomatem II, op. cit., pp. 25-28, 129-133. 
good, compared to the bodily and the external. Even then, the theological virtues were necessary to complement the cardinal virtues to «bestow a tranquil mind. ${ }^{69}$

Later in the letter, Pius addressed the nature of the «highest good» (summum bonum). In that context, the text compares the Christian and Muslim ideas of this human good. This discussion begins with a swipe at the «nonsensical features» of Islam lacking foundation in Scripture or philosophy. The creator was not a corporeal being and, in His providence, cared for all creation. ${ }^{70}$ It is the soul, not the body, which is created in the divine image. ${ }^{71}$ Pius was able to pass from these generalities to an attack on polygamy as against "natural liberty.» God, he said, would not have created a single helpmate for Adam if polygamy were divinely approved. Moreover, he argued that this limited the number of potential wives. Some men «in one and the same city enjoy polygamy and others must live in solitude.» These unmarried men would produce no offspring. ${ }^{72}$

Having attacked polygamy, Pius promised Mehmed that baptism would make him "powerful while you are alive and blessed after death while you are in heaven. $\rangle^{73}$ After making these promises, Pius segued into an attack on the Prophet as clever but not good. «All his law is artifice and fraud.» ${ }^{74}$ Muhammad

${ }^{69}$ Piccolomini, Epistola ad Mahomatem II (Glei), pp. 28, 133, «Philosophi, quod peripateticos vocavit antiquitas, tria bonorum genera posuerunt: et alia esse animi dixerunt, alia corporis, alia externa. Stoici ea dumtaxat, bona existimarunt quae animum excolerent: hoc facit iustitia, prudentia, moderatio, fortitude et quae sunt aliae in animo dotes... Sed neque illae quattuor virtutes, quae principales existimarunt, tranquillam homini mentem reddunt, nisi aduniantur aliae tres, quae theologicas appellant, et in animo sitae sunt: spes, fides, caritas.»

${ }^{70}$ Piccolomini, Epistola ad Mahomatem II (Glei), pp. 67-68, 173-174.

${ }^{71}$ Piccolomini, Epistola ad Mahomatem II (Glei), pp. 69, 175.

${ }^{72}$ Piccolomini, Epistola ad Mahomatem II (Glei), pp. 69-70, 176, «Nec propterea numerus hominum augetur, quia plures uni nubant feminae: nam totidem viri private coniugio sine prole decedent et praesertim cum mulieres numero pauciores existant. Iniqua insuper res videtur et naturali adversa libertati unius urbis civium alios multiplici matrimonio uni, alios in solitudine degree.»

${ }^{73}$ Piccolomini, Epistola ad Mahomatem II (Glei), pp. 74, «Age igitur: accipe Christianos socios, accipe fidem et baptismum, qui te hic in terries faciet magnum quoad vixeris, et post obitum in caelo beatum reddet.» Pius also said there were few illustrious Muslims, like Saladin, but many renowned crusaders; see op. cit., pp. 74, 180. On the Western view of Saladin, see Tolan, J.V., Sons of Ismael. Muslims Through European Eyes in the Middle Ages, Gainesville, University of Florida Press, 2008, pp. 79-100.

${ }^{74}$ Piccolomini, Epistola ad Mahomatem II (Glei), pp. 75, 181, «Tota est artificiosa et fraudulentia lex eius.» 
promised a law «laxer than the Christian» (laxiori lege tenerentur quam Christiani), which commended continence, not the "attractive pleasures» (voluptatem ... amicam) promised by Islam. This won over many, whereas even the pagan philosophers were «lovers of virtue» (virtutis amatoribus). ${ }^{75}$ Pius blamed the growth of Islam on «license given to vice.» This covered polygamy and men "sending away [those wives] who displeased them». He also denounced indulging the mouth «with everything except wine.» In hot Arabia, they could have "cool drinks" instead. ${ }^{76}$

The pope dismissed street corner preachers and pseudo-prophets implying that Muhammed was one of them. Resorting to Roman history, Pius referred to the Bacchanalians of ancient Rome, who were inclined to lust: «Deceivers and false prophets preach on street corners and wish what they say to remain hidden, and they exact oaths of silence. This is just like what happened at Rome where those who celebrated the Bacchanalia, sacrificing to their god in secret, omitted no outrage of lust». ${ }^{77}$

Pius summarized by saying: "The Law of God is pure because it excludes every sort of evil and does not admit any lust or foul thing... But how can the law of Mohammed be pure which allows foul practices, adultery, everything lustful and foul? $\gg^{78}$ Pius added a contention that only Muslim lawgivers hhave placed adultery, fornication, serving the belly, living in filthy pleasures, among good things.» Pius also compared Mohammed with heretics, who mix good things in with the bad in order to deceive: "Only Mohammed promotes turpitude and only he advances shameful practices, even mixing the good with the bad, the way heretics do, in order to deceive more easily.» ${ }^{79}$

${ }^{75}$ Piccolomini, Epistola ad Mahomatem II (Glei), pp. 75, 181.

76 Piccolomini, Epistola ad Mahomatem II (Glei), pp. 75, 181, «Crevit igitur secta Saracenorum licentia vitiorum: placuit uxoris decere quot mallent easdemque dimittere quam cum displicere coepissent, habere concubinas quam plures et omne libidinis genus posse prosalvi; indulgere ventri cuncta quae vellet et ori, praeter vinum, et universis immerge voluptatibus.» Pius added that Muslim fasts only increased the pleasures of feasting and drinking at night.

77 Piccolomini, Epistola ad Mahomatem II (Glei), «Deceptores et pseudoprophetae in angulis praedicant et volunt occulta esse, quae dicunt, et iuramenta taciturnitas exigunt. Sicut Romae accidit in his, qui Bacchanalia celebrant: in occulto enim deo suo sacrificantes nullum flagitium libidinis omittebant.»

${ }^{78}$ Piccolomini, Epistola ad Mahomatem II (Glei), pp. 88, 195, «Immaculata est lex Domini, quia mala quaeque excludit, neque libidem neque turpitudinem ullam admittit.... At quomodo Mahumetes lex immaculata, quae sturpra et adulteria et omnes libidum maculas et foeditates admittit?»

${ }^{79}$ Piccolomini, Epistola ad Mahomatem II (Glei), pp. 89-90, 196, «Solus Mahumetes est qui turpia docet et flagitia praecipit, quamvis haereticorum more, ut facilius decipiant, bona simul et mala commiscet.» 
The three curialists we have studied all dismissed Islamic ideas of paradise as lustful and filthy. Torquemada was the most forthright in his condemnation of Islam. He found little good in the texts he had read about Islam. Cusanus tried harder to find Gospel truths in the Qur'an. Pius combined persuasion with outright polemic in a way that was unlikely to move the Ottoman sultan to convert. (Even John of Segovia, a well-known advocate of dialogue with Muslims, was dismissive of the perceived carnality of Muslims and their view of the afterlife as full of creature comforts..$^{80}$ ) These writers shared a cultural background which made their polemics possible, viewing human happiness as intellectual or spiritual. Their idea of heaven treated the eternal reward of the just as the vision of God, the Beatific Vision. Even the resurrected body, although completely human, including the two genders, was possessed of characteristics like impassibility, an opinion which left no room for the more bodily paradise promised by the Prophet. ${ }^{81}$ Cusanus tried to find the Gospel hidden in the Qur'an, and Piccolomini tried persuading Mehmed II to embrace the Christian faith by offering him heaven and earth. Only Torquemada adhered to the most negative line in the long-time Christian rejection of Islam, and that dismissal of the Prophet and his teachings would have a long subsequent history even among those who had not read the Dominican cardinal's polemic.

Thomas M. Izbicki

tizbicki@libraries.rutgers.edu

${ }^{80}$ John of Segovia, De gladio divini spiritus in corda mittendo Sarracenorum, op. cit., vol. 2, pp. 740-741, 846-847, 862-865. Mann, «John of Segovia», op. cit., pp. 150, 153.

${ }^{81}$ Augustine, who thought late in life that the resurrected body of Jesus had flesh and bones, said risen bodies would have youth and beauty but no need to eat for sustenance; see McDannell, C., and B. Lang, Heaven. A History, New Haven, Yale University Press, 1988, pp. 6162 . The Beatific Vision was discussed by the Scholastics and medieval mystics; see op. cit., 89-91, 93, 101-102, 106. 